\title{
Contribution of the Holy Bible in the making of the Mahatma
}

\author{
V. RamyaRajasri Kumar \\ IInd Year, B.A.LL.B (Hons.), National Academy of Legal Studies and Research, University of \\ Law(NALSAR),Hyderabad, India.
}

\begin{abstract}
Mahatma Gandhi and Gandhian principles have been followed with great sense of reverence ever since he fought for India's Independence from the British colonial rule. Gandhi is known for using techniques of non-violence to help India achieve independence. However what hasn't been discussed enough is the source of inspiration for most of the principles propounded by Mahatma Gandhi. The researcher through this paper aims to bring to light the lesser known fact about the kind of influence the Holy Bible and Jesus Christ, in particular, have had on Gandhi and Gandhian Principles with the help of sufficient supporting evidence to understand the same.
\end{abstract}

Keywords: Mahatma Gandhi, Gandhian Principles, Source of Inspiration, Holy Bible, Jesus Christ.

\section{Introduction}

1. Mahatma Gandhi

Mohandas Karamchand Gandhi popularly known as Mahatma Gandhi or Bapu was born on $2^{\text {nd }}$ October 1869 in Porbandar which was part of the then Bombay Presidency under the British rule. His father Karamchand Gandhi served as the diwan of Rajkot State. ${ }^{1}$ In May 1883, 13 years old Gandhi married Kasturba, who was 14 years old. In 1885 Gandhi's father passed away and subsequently in the year 1887 he cleared the matriculation examination set by the University of Bombay and thereafter joined the Samaldas College in Bhavnagar. After much contemplation he went to London in order to pursue his higher studies because his parents wanted him to become a barrister as they thought it would increase his prospects in succeeding his father's post. ${ }^{2}$

He came back to India in July 1891 only to realize that his mother had passed away in his absence. To his dismay he discovered that the barrister degree he held didn't guarantee him a lucrative job so he went back to Rajkot and drafted petitions for litigants to earn a living. After exploiting all opportunities he accepted a yearlong contract with an Indian firm established in South Africa. ${ }^{3}$

Gandhi had bitter experiences in South Africa, from being unceremoniously thrown out of the first class compartment of the train to being beaten up by a white driver of the stage coach for refusing to give extra respect to the European passengers, he faced heaps of humiliation. These bitter experiences carved out his personality and played a major role in molding his ideologies and philosophies.

"What he did to South Africa was indeed less important than what South Africa did to him. It had not treated him kindly, but, by drawing him into the vortex of its racial problem; it had provided him with the ideal setting in which his peculiar talents could unfold themselves"

In1915 Gandhi returned back to India permanently and gained cognizance of the then prevailing conditions in terms of politics, economy, culture, trade and industry. He joined the Indian National Congress and escalated their demands from asking for mere autonomy to complete independence. What made him stand out from the other freedom fighters was his approach to fight for independence. He used principles of Satya (truth) and ahimsa (non-violence) to fight the oppressive British colonial power. Mahatma Gandhi, who was now popularly known as Bapu led the non-cooperation movement, the dandi march followed by the civil disobedience movement. All these movements proved to be effective and left a huge impact on the oppressors as well as the Indians. The novel technique of non- violence agitation namely, Satyagraha is till date revered and followed. ${ }^{5}$ With the help of unconventional tools he managed to cross every hurdle that came his way. He led

\footnotetext{
${ }^{1}$ Uma Majmudar,Gandhi's Pilgrimage of Faith: From Darkness to Light(New York: State University of New York Press, 2005),p.27, available at:

http://books.google.co.in/books?id=xM4paHEq5oQC\&printsec=frontcover\&dq=gandhi's+pilgrimage + of + faith + from +darkness+to+light+uma+majmudar\&hl=en\&sa=X\&ei=8jBLUaLiJcTQrQf7uoGACA\&ved=0CC4Q6AEwAA(last visited on March $21^{\text {st }} 2013$ ).

${ }^{2}$ Mahatma Gandhi, Ch-Preparation for EnglandinThe Story of My Experiment with Truth (The Floating Press, 2009),pp.18-20.

${ }^{3}$ Mohandas Karamchand Gandhi(Indian leader), available at: http://www.britannica.com/EBchecked/topic/225216/Mohandas-KaramchandGandhi/22632/England (last visited on March $21^{\text {st }} 2013$ ).

${ }^{4}$ Ibid.

${ }^{5}$ Mohandas Karamchanda Gandhi, available at:http://www.ams.sunysb.edu/ saurabh/philosophy/mkg.html (last visited on March $21^{\text {st }}$ 2013).
} 
India to its independence which was officially declared on august $15^{\text {th }} 1947$. He brought down the British raj with the help of non-violence and brotherhood.

Today he is seen on every currency note an Indian carries, thousands of streets, commissions, reports are named after him or are inspired by his principles. Gandhi is referred to as the father of the nation. $\mathrm{He}$ epitomizes indefatigability, tolerance and tranquility. He is still considered to be one of the greatest men of all times, who not only propagated pacifism but left a discernable imprint on the history of India.

What people don't talk much about is the source of this inspiration for Gandhi. Not many know that the holy bible has played a pivotal role in shaping Gandhiji's ideologies and perceptions about the world in general.

In the course of this project the researcher aims to elucidate on the fact that Jesus Christ has been one of the major sources of inspiration for Gandhi. The researcher will also try to relate the various teachings of Jesus Christ and the Bible to the Gandhian principles.

\section{Introduction}

\section{A Tryst With The Bible}

Gandhi from the age of nineteen had been an avid reader of all kinds of religious scriptures including, the Bible, the Koran, the Bhagvat Gita, the AdiGranth, the Avesta and various scriptures like the Upanishads, Puranas, Vedas and Ramayana. He considered it to be a 'sacred duty' for every person to read and learn from these sagacious scriptures. ${ }^{6}$

In 1889 as a student of law in London Gandhi promised his friend that he would read the Bible, So he started with the Old Testament and moved on to the new testament which was more appealing to him as compared to the previous testament. What autobiographies don't mention is the fact that, four years after this incident he went to South Africa and met three different groups of people who tremendously inspired and influenced him. ${ }^{7}$

Gandhi's experiences in South Africa carved him into the Mahatma today everyone knows. He was imprisoned three times in South Africa and all three times he spent his time reading and experimenting with truth, as he called it. Gandhi read religious books and other books written by Tolstoy and Ralph Waldo Emerson which helped him understand the Bible better.

Gandhi essentially learnt about the Bible in three stages which are going to be dealt with in the next section of this chapter.

\subsection{The first wave- The Esoteric Christian Union}

A London based group called the Esoteric Christian Union, led by Edward Maitland and Anna Kingsford, was the first source of influence for Gandhi, they played a major role in molding his understanding of the Bible. It had broken away from the London lodge of the theosophical society in 1884. Gandhi was more drawn to the idea of vegetarianism propagated by Kingsford than feminism or Hinduism; he represented the Esoteric Christian Union ${ }^{8}$ and soon began to advertise their writings in the Natal Mercury. ${ }^{9}$ This could be attributed to their books, The Perfect Way, or the finding of Christ (1882) and The New Gospel of Interpretation (1892) as these had an immense amount of impact on Gandhi. ${ }^{10}$

With the help of esoteric Christianity's mystical interpretation of the Bible, Gandhi learnt to oppose materialism and view the bible as the 'book of the soul'. ${ }^{11}$ Even though the influence of the esoteric union hasn't received much credit it remains to be one of the most influential sources for Gandhian principles, it is evident in the writings of the Mahatma.

"unmistakable signs of a return from the materialistic tendencies, which have made us so cruelly selfish, to the unadulterated esoteric teachings of not only Jesus Christ, but also of Buddha, Zoroaster and Mahomed, who are no longer so generally denounced by the civilized world as false prophets, but whose and Jesus's teachings are beginning to be acknowledged to be complementary of one another" ${ }^{\prime 2}$

\footnotetext{
${ }^{6}$ William W. Emilsen, Gandhi, scripture and Bible,Pacifica Australasian Theological Studies, vol. 14, no.1, (2001),p.73, available at:http://paa.sagepub.com/content/14/1/71.full.pdf (last visited on March $22^{\text {nd }} 2013$ ).

${ }^{7}$ Ibid at p.77.

${ }^{8}$ Kathryn Tidrick, Gandhi: A Political and Spiritual Life (I. B. Tauris, 2006), p.42, available at:

http://books.google.co.in/books?id=ppgZ5OVkuUC\&pg=PA42\&lpg=PA42\&dq=esoteric+christian+union,+london\& source=bl\&ots=4ckW0UGurR\&sig=GLK0PEAaGXIYcdWtlmVQTh4RfRo\&hl=en\&sa=X\&ei=jkdMUY7vN8r_rAff nIGQCA\&ved=0CEIQ6AEwAw\#v=onepage \&q=esoteric\%20 christian\%20union\%2C\%20london\&f=false (last visited on March $22^{\text {nd }}$ 2013).

${ }^{9}$ Gandhi, Letter to The Natal Mercury, 26 November 1894.

${ }^{10}$ Emilsen, Supra n.6 at p.77.

${ }^{11}$ Ibid at p.78.

${ }^{12}$ M.K.Gandhi, Letter to The Natal Advertiser, $21^{\text {st }}$ January 1895.
} 


\subsection{The second wave- The Evangelical Nonconformists Protestants}

The Nonconformist Protestants, which include Wesleyans, Presbyterians, Baptists, Quakers and Congregationalists, they have been instrumental in influencing Gandhi to read the Bible and understand both Jesus Christ and Christianity in general. These nonconformists staunchly supported Gandhi's passive resistance and helped him value the disciplined study of the Christian scriptures. According to William W. Emilsen: "These Protestant awakened the 'religious quest' within Gandhi"13

Gandhi thoroughly read the Bible and Joseph Parker's commentary, 'the people's Bible: Discourses upon the Holy Scriptures' (1889), and gained a new insight into the institution of Christianity.

\subsection{The third wave- Leo Tolstoy}

Gandhi revered the Russian writer Leo Tolstoy and claimed to be a humble follower of the great writer. Gandhi was astounded by Tolstoy's 'The Kingdom of God is Within You' (1893) and admired his biblical studies. Tolstoy's ideology which gave soul force greater importance than brute force greatly influenced Gandhi and invigorated his movement of non-violence and Satyagraha. ${ }^{14}$ These movements proved to be highly effective and proved to be a true reflection of the doctrine of superiority of soul force over brute force.

Gandhi also read other religious works of Leo Tolstoy such as, 'Christianity and Patriotism' (1894), 'Translation and Harmony of the Gospels' (1880-81) and 'What to do?' (1887). These works of Tolstoy helped mold Gandhi's perceptions and ideologies with regard to the New Testament and Sermon on the Mount. ${ }^{15}$

\section{Introduction}

\section{Gandhi's Interpretation of the Scriptures}

Gandhi venerated Bible and Bhagvat Gita equally but never claimed to be a full-fledged Christian as he read the Holy Bible with different lens. Gandhi had often said that he admired Jesus Christ but didn't like Christians because the materialism, affluent Christian countries displayed contradicted the claims of Jesus Christ which said that it's not possible to worship both Mammon and God at the same time. ${ }^{16}$

So every time he picked up the holy bible, he read it critically and only imbibed in what he felt was right. When missionariesseeked help from Gandhi, he advised them to read the Hindu scriptures from the lens of a Hindu and Koran through the eyes of a Muslim just as they would expect him to read the bible like a Christian. ${ }^{17}$

In the next section the researcher will be dealing with the various filters adopted by Gandhi to critically interpret the Holy Bible.

\subsection{The Acid Test of Reason}

Gandhi said that god's words shouldn't be taken literally instead one should understand the underlying meaning behind each word and apply accordingly. He said that every scripture needed to pass the test of reason to be worthy of being followed and applied to life. ${ }^{18}$

Gandhi had no hesitation in rejecting any religious text if it did not clear the test of reason. For example the Manusastra talks about 'untouchability' but Gandhi didn't consider it as an authority and firmly rejected it. Similarly he opposed the stand the Christians took using Bible as their authority with regard to capital punishment. Thus Gandhi said any teaching or word said by god or any religious text must be rejected if it wasn't reasonable. ${ }^{19}$

Later he realized that terms such as reason and reasonability were subjective in nature and could be molded in favor of the interpreter. For instance the Muslims justified the practice of stoning using the Koran as their authority ${ }^{20}$. Therefore Gandhi set up another test of interpretation which will be discussed in the next section of this chapter.

\footnotetext{
${ }^{13}$ Emilsen, Supra n.6 at p.78.

${ }^{14}$ Mohandas Gandhi, Soul Force: Gandhi's Writings on Peace (Tara Publishing Ltd. 2004), p.67, available at:http://books.google.co.in/books?id=Wwkt5TX623UC\&pg=PA67\&lpg=PA67\&dq=tolstoy+-

+soul+force+superior+to+brute+force \&source=bl\&ots=wBfwgzdmBx\&sig=I7t4Zo-

_jodXVD1PtsG7XFbc9II\&hl=en\&sa=X\&ei=C2NMUf_SBI7xrQer3oDQAw\&ved=0CE8Q6AEwBQ\#v=onepage\&q= tolstoy\%20-\%20soul\%20force \%20superior\%20to\%20brute\%20force \&f=false (last visited on March $22^{\text {nd }} 2013$ ).

${ }^{15}$ Emilsen, Supra n.6 at p.79.

${ }^{16}$ Available at: http://www.brainyquote.com/quotes/quotes/m/mahatmagan107529.html (last visited on March $22^{\text {nd }} 2013$ ).

${ }^{17}$ The Stupendous Bhagvat Gita, available at: http://www.hinduwisdom.info/Glimpses_X.htm (last visited on March 23 ${ }^{\text {rd }}$ 2013).

${ }^{18}$ M. K. Gandhi, Dr. Ambedkar's Indictment-II, available at: http://ccnmtl.columbia.edu/projects/mmt/ambedkar/web/appendix_1.html (last visited on March $22^{\text {nd }} 2013$ ).

${ }^{19}$ Emilsen, Supra n.6 at p.75.

${ }^{20}$ One such instance is available at: http://atlasshrugs2000.typepad.com/atlas_shrugs/2011/05/muslim-girl-19-stoned-to-death-after-takingtaking-part-in-beauty-contest-muslim-youths-killed-her-c.html (last visited on March $22^{\text {nd }} 2013$ ) in this case a 19 year old girl was killed and her battered body was found in the forest after she was missing for weeks. The reason behind this gruesome act was, her participation in a beauty contest and the culprits justified themselves by saying that she went against the Sharia Law.
} 


\subsection{The Test of Morality and Conscience}

Another test the religious scriptures were put through was the test of morality. Gandhi said anything that was incongruous with the doctrine of non-violence and moral sense was to be avoided. ${ }^{21}$

Gandhi renounced everything that was against morality for example Tulsidas's Ramayana said, "the drum, the fool, the sudra, the animal and the woman- all these need beating" ${ }^{22}$ Even though he had profound respect for Tulsidas, Gandhi firmly opposed this as it was immoral and against the doctrine of non-violence. ${ }^{23}$ He took a stand that scriptures weren't meant to be taken literally and that any scripture that wasnot in consonance with the 'infallible canon of interpretation' must be firmly rejected.

\section{Biblical interpreter}

As a bible interpreter Gandhi differed from the Christians. First because he read it with a critical lens and sufficiently filtered every word he read, unlike most of the Christians who took the Bible literally. Second Gandhi not only read it critically but also read it in the Hindu context. Gandhi has often claimed to have gained a better understanding of the Bhagvat Gita after reading scriptures like The Holy Bible he has also said that he could relate to it better and therefore felt that he became a better Hindu.

\section{3.}

\section{Old Testament}

Gandhi didn't honor the Old Testament as he honored the New Testament; according to him the Old Testament consisted of 'blood and thunder' and propagated the doctrine of 'an eye for an eye'. He felt an unmistakable difference between the god of the Hebrews and the god of Jesus Christ.Nevertheless he imbibed a lot from the Old Testament as well; he read nine books in all including, Genesis, Exodus, I Kings, Job, Psalms, Proverbs, Isaiah, Daniel and Jonah.

The book of Daniel appealed to him, in particular chapter 6 where Daniel is thrown into a pit of lions because he disobeyed the laws of the Medes and Persians and prayed thrice a day. ${ }^{24}$ Gandhi's interpretation to this verse is quite different; he sees it as the purest form of Satyagraha, a portrayal of active resistance. Gandhi often referred to Daniel as the epitome of passive resistance, he drew immense amount of inspiration from him. $^{25}$

\section{New Testament}

Bapu was however more drawn to the New Testament; he felt that one's life would be incomplete if one doesn't incorporate the teachings of Jesus in his or her ways of life. ${ }^{26} \mathrm{He}$ referred to Christ as one of the greatest teachers humanity has seen and followed his path of righteousness.

\section{Book of Matthew}

What attracted Gandhi was the Sermon on the Mount ${ }^{27}$ he called himself the 'Sermon on the Mount Christian, ${ }^{28}$ and advised people to follow it to attain true happiness and to end misery. Both Matthew and Gandhian principles say that one who bears suffering, poverty, renounces the materialistic world and worldly rewards, is rewarded in the kingdom of god.

With the help of Book of Matthew, the Mahatma learnt to distinguish between passive resistance and non-violent resistance and observed that the Europeans mistook Christ's bold resistance to be passive resistance as he saw no passivity or weakness in Christ after reading the gospels. ${ }^{29}$ One will find references in the bible where in Jesus Christ tells his disciples that fasting shouldn't be done to show the public but should be done to

\footnotetext{
${ }^{21}$ Gandhi and Comparative Religion(presented at the $12^{\text {th }}$ World Congress of Philosophy, Boston, 1998), available at: http://www.bu.edu/wcp/Papers/Comp/CompBaru.htm (last visited on March $23^{\text {rd }} 2013$ ).

${ }^{22}$ Emilsen, Supra n.6 at p.75.

${ }^{23}$ Hindi Swaraj and Gandhi's conquest for power, available at: http://www.crvp.org/book/Series03/IIIB-5/chapter_i.htm (last visited on March 23 ${ }^{\text {rd }}$ 2013).

${ }^{24}$ The Holy Bible, Good News Ed., Old Testament, p.861.

${ }^{25}$ Emilsen,Supra n.6 at p.81.

${ }^{26}$ Dr. SarvepalliRadhakrishnan, Mahatma Gandhi (Mumbai: Jaico Publishing House, 2007), p.480, available at:http://books.google.co.in/books?id=RKBb4SdxQhAC\&pg=PA558\&lpg=PA558\&dq=praising+mahatma+gandhi \& source $=$ bl\&ots $=\_$myB9Q5p0\&sig=DGkGdU8aH2H0jI-

E7FPTdu $1 \times 7 \mathrm{Gg} \& \mathrm{hl}=$ en\&sa=X\&ei=miZLUayiL8KsrAed84HgAQ\&ved=0CFIQ6AEwBA\#v=onepage\&q=praising\%

20mahatma\%20gandhi\&f=false (last visited on March $23^{\text {rd }} 2013$ ).

${ }^{27}$ The Holy Bible, Good News ed., New Testament, Matthew 5:3-12, p.7.

${ }^{28}$ The world's greatest Hindu became the greatest exemplar of Sermon on the Mount, available at: http://www.mkgandhi.org/articles/harriswofford.htm (last visited on March 23 ${ }^{\text {rd }} 2013$ ).

${ }^{29}$ Letter to Madame Edmond Privat, available at: http://www.gandhi-manibhavan.org/gandhicomesalive/comesalive_letter32.htm(last visited on March $23^{\mathrm{RD}} 2013$ ).
} 
please your lord. ${ }^{30}$ Here Gandhi differed by publically fasting because it was necessary to bring about change in the then prevailing political scenario.

\section{Jesus Christ}

Gandhi considered Christ to be the greatest teachers of all times however there were certain things he refused to believe. He never believed that Christ rose from the dead. ${ }^{31}$ According to him there are two aspects of Christianity, perspective, refers to worship and descriptive refers to abiding by Christ's teachings. He claimed that the perspective aspect was ancillary to the descriptive aspect. ${ }^{32}$

Interestingly, as mentioned before, he interpreted the bible and Christ's life in the Hindu context. Example:The Book of Matthew talks about how Jesus was put to test in the wilderness after fasting for forty days and forty nights. The devil tempts Jesus to turn stones into bread to satiate his hunger, and then he asks Jesus to jump off a cliff to test the word of God and also offers Jesus, wealthy kingdoms to induce him into worshipping him..$^{33}$

Gandhi believed that by conquering the first temptation of hunger, one gains mastery over his senses, and in turn gains strength, which in itself is a temptation to vanquish. Once one gains mastery over his strength then he attains siddhis, which are miracle powers and these siddhis are considered to be the third temptation. ${ }^{34}$ Gandhi admired Jesus and often related to him, one such instance would be when he began the Dandi March in 1930, where he drew a parallel between his march and the march led by Jesus in Jerusalem. ${ }^{35}$

\section{Introduction}

\section{Principles Adopted From The Bible}

In this section the researcher aims to scrutinize Gandhian principles in light of the teachings of the bible and Jesus Christ in particular, signifying the influence Christianity had on Bapu.

Most of the Gandhian principles have been derived from the Holy Bible and there have been sufficient evidence to prove the same. Gandhi on many occasions has advised people to read and apply Christ's teachings to understand the meaning of true happiness and to lead a better life. In the next section the researcher has listed down the principles and subsequently has studied them in detail in light of the biblical references.

\section{Teachings of the Bible}

There are a plenty of things which Gandhi adopted from the Bible, some of them are as follows:

\subsection{An eye for an eye turns the whole world blind}

These were Gandhi's words ${ }^{36}$ which gained popularity but what has not been sufficiently publicized is the fact that these words have been adopted from the Holy Bible. This doctrine has been stated in Matthew $5: 38^{37}$

This principle can be seen as the nucleus of Gandhian principles as this essentially preaches nonviolence or ahimsa.

\subsection{Turn the other cheek}

But I say unto you, that ye resist not evil: but whosoever shall smite thee on thy right cheek, turn to him the other also. (Matthew 5:39 KJV) One of the many biblical references which Gandhi applied was the principle of turn the other cheek. He was often seen propagating this principle as a part of the non-violence movement. ${ }^{38}$

\footnotetext{
${ }^{30}$ Matthew 6:16-18.

${ }^{31}$ Mahatma Gandhi, Robert Ellsberg (Ed.), Gandhi on Christianity (New York: Orbis Books, 1991),p.94, available at: http://books.google.co.in/books?id=yGvYAAAAMAAJ\&q=gandhi+on+christianity\&dq=gandhi+on+christianity\&hl=en\&sa=X\&ei=DYVN UbL_DMHqrAfVxoCIBw\&ved=0CC4Q6AEwAA (last visited on March 23 ${ }^{\text {rd }}$ 2013). 


\subsection{Love for enemies}

Gandhi followed the teachings of the Christ, with regard to loving one's enemies and praying for your persecutors as mentioned in Matthew 5:44. ${ }^{39}$ The Mahatma had often said loving one's enemy would help invigorate the cause of Satyagraha by winning your enemies over to one's own side. ${ }^{40}$

\subsection{Humility}

Gandhifirmly believed that humans are mere grains of sand and there is no reason for a person to be supercilious and pompous. Thus he believed that everyone should be humble and altruistic. ${ }^{41}$ The can be seen in the Bible, For dust thou art, and unto dust thou shalt return. (Genesis 3:19)

\subsection{Bread labor}

In the sweat of thy brow shalt thou eat bread. (Genesis 3:19)Both bible and Gandhi lay stress upon the fact that a man has to work hard to earn his bread and money. ${ }^{42}$ This is also the reason why Gandhi was seen spinning his own clothes which in turn helped Indians to attain 'real swaraj' ${ }^{43} \mathrm{He}$ also identified the sameteachings in the third chapter of the Bhagvat Gita and called it Yajna. As per Gandhian principles and Tolstoy, anyone who didn't perform Yajna was considered to be a thief. ${ }^{44}$

Gandhi also said if everyone earned just the right amount of bread, sufficient for the person who worked for it then the world wouldn't have to see overpopulation, the class divide between the rich and poor, discrimination between upper and lower caste groups. ${ }^{45}$

\subsection{Honorable Exile}

Gandhi had identified different techniques of Satyagraha; 'Hijrat' was one of them. ${ }^{46}$ It literally meant migration from one place to another but on the whole it meant taking a self-imposed exile. This has also been mentioned in the second book of the Old Testament with reference to the planned fight of the Israelites. ${ }^{47}$

\subsection{Non-Cooperation}

Gandhi's non-cooperation movement was one of the strongest weapons used against the hegemonic power that ruled in India. Gandhi, as mentioned in the previous chapter considered Daniel to be one of the greatest passive resisters and took inspiration from him after reading certain verses from the book of Daniel. ${ }^{48}$ There have been many instances where Gandhi has been seen accepting this. ${ }^{49}$ Gandhi had taken Jesus Christ as his greatest inspiration; he had also observed that the crucifixion of Christ was the best demonstration of Satyagraha and passive resistance..$^{50}$

\subsection{Fast unto death}

In the book of Matthew, Jesus tells his disciples that nothing in the world is impossible, if a man wants to move a mountain from one place to another it is possible with the help of prayers and fasts. ${ }^{51}$ It is from here that Gandhi adopted the method of fasting. Gandhi would go on a 'fast unto death' to protest against issues he felt were troublesome, for example on $12^{\text {th }}$ September 1932 he went on a perpetual fast in protest of the caste

\footnotetext{
${ }^{39}$ Supra n.34.

${ }^{40}$ Gandhi's principles of Satyagraha, available at: http://satyagraha1.com/gandhihow.htm (last visited on March 23 ${ }^{\text {rd }} 2013$ ).

${ }^{41}$ Mahatma Gandhi, William W. Emilsen,Gandhi's Bible (New Delhi: The Rev. Dr. Ashish Amos of Indian Society for Promoting Christian Knowledge, 2009), p.2available

at:http://books.google.co.in/books?id=5wWnuJ4GacUC\&printsec=frontcover\&source=gbs_ge_summary_r\&cad=0\#v=onepage\&q\&f=false (last visited on March $23^{\text {rd }} 2013$ ).

${ }^{42}$ Galantians 6:7 (KJV).

${ }^{43}$ Michael J. Nojeim, Gandhi and King: The Power of Non-Violent Resistance (Greenwood Publishing Group,

2004), available at:

http://books.google.co.in/books?id=lme8yEeWOr8C\&pg=PA113\&dq=gandhi+made+his+own+clothes\&hl=en\&sa=

X\&ei=lFpZUe5G8HVrQfm9oG4Bg\&ved=0CC8Q6AEwAA\#v=onepage\&q=gandhi $\% 20 \mathrm{made} \% 20 \mathrm{his} \% 20 \mathrm{own} \% 20 \mathrm{cl}$

othes $\& \mathrm{f}=$ false (last visited on April $1^{\text {st }} 2013$ ).

${ }^{44}$ Ibid at p.4.

${ }^{45}$ Gandhi, supra n.41 at p.5.

${ }^{46}$ Gandhian philosophy of Satyagraha, available at: http://www.mkgandhi.org/articles/ramanand.htm(last visited on March $24^{\text {th }} 2013$ ).

${ }^{47}$ Exodus 3:17-18 (KJV).

${ }^{48}$ Daniel 6:7-13 (KJV).

${ }^{49}$ M.K. Gandhi, My Dear Child: Letters from M.K.Gandhi to Esther Faering (Navajivan, 1959), available at:

http://books.google.co.in/books/about/My_dear_child.html?id=CAjVAAAAMAAJ\&redir_esc=y (last visited on March 24 $\left.{ }^{\text {th }} 2013\right)$.

${ }^{50}$ Gandhi, supra n.41 at p.105.

${ }^{51}$ Matthew 17:20-21 (KJV)
} 
separation $^{52}$. Gandhi compared his fast with the one kept by the king and his people of Nineveh for god's deliverance. ${ }^{53}$ Till date this method of Satyagraha is recognized and used. ${ }^{54}$

\subsection{Holding unto the truth}

The term Satyagraha, which essentially means to hold on to the truth, was coined by Gandhi in South Africa when Indians struggled for rights. ${ }^{55}$ Gandhi used this term with soul force and often said that he could give up his nation for truth and non-violence. ${ }^{56}$ However the lesser known fact is that Gandhi was inspired by Christ on this note, this principle is mentioned in the bible;let us not love in word or talk but indeed and in truth. (John 3:18). He was also of the opinion that Christ was the greatest vow-keeper and thus laid emphasis on keeping vows as well. ${ }^{57}$

\subsection{Expression of Love}

Gandhi believed that expressing one's love was in itself a form of self-sacrifice and this was in consonance with the principles of Satyagraha. ${ }^{58} \mathrm{He}$ imbibed the idea of expressing one's love from the first epistle of Corinthians. ${ }^{59}$ Gandhi was so drawn to it that he even sent a copy of it to his nephew, Mangalal and asked him to read it to gain a new insight on love and life. Time and again Gandhi had asked people to read Corinthians and equated love with truth. ${ }^{6}$

\subsection{Principle of Brahmacharya}

Gandhi's experiments on Brahmacharya were basically aimed at gaining control over one's thoughts, words, action and desires at all times. ${ }^{61} \mathrm{He}$ tried leading a life of a Brahmacharya because he believed, 'without Brahmacharya a Satyagrahi has no lustre'. This view has been inspired from the bible, which warns people about the traps of the superficial lust, ${ }^{62}$ and asks them to flee from lust to pursue righteousness, faith, love and peace. $^{63}$

\subsection{2. 'Be Careful for Nothing'}

Gandhi quoted the biblical text very often; in particular the verse given below was referred to in every aspect of his life. ${ }^{64} \mathrm{Be}$ careful for nothing; but in everything by prayer and supplication with thanksgiving let your requests be made known unto God. (Philippians 4:6).

According to Gandhi the principle of 'be careful for nothing' gave oneself composure, contentment, discipleship and instilled in the readers trust and faith in god. He often advised his disciples to observe the wisdom of this verse and to stop agonizing about ones future as it was futile. ${ }^{65}$

\section{Conclusion}

Mahatma Gandhi, the father of our nation, led India to its independence. When all else failed his unconventional techniques like, the doctrine of non-violence and Satyagraha were instrumental in bringing about political and social progress. He is considered to be the epitome of pacifism, perseverance and symbolizes peace.

\footnotetext{
${ }^{52}$ SankarGhosh, Mahatma Gandhi (New Delhi: Allied Publishers Limited, 1991),p.229, available at: http://books.google.co.in/books?id=510BPnxN1h8C\&pg=PA229\&dq=gandhi+fast + unto+death\&hl=en\&sa=X\&ei=vJ5OUbCDN42yrAeXto DYBQ\&ved=0CDoQ6AEwAg\#v=onepage \&q=gandhi\%20fast\%20unto\%20death\&f=false (last visited on March $24^{\text {th }} 2013$ ).

${ }^{53}$ Jonah 3:5-10 (KJV).

${ }^{54}$ Anna hazare begins his fast unto death, available at:http://www.timesnow.tv/Anna-begins-fast-unto-death/articleshow/4407294.cms (last visited on March 24 $4^{\text {th }} 2013$ ). "A social activist, rose to fame in 2011 when he went on a fast unto death protesting against corruption, following Gandhian principles. ”

${ }^{55}$ Gandhi, supran.41 at p.25.

${ }^{56}$ Ambuj Kumar Sharma, Gandhian Strain in the Indian English Novel (New Delhi: Sarup\& Sons, 2004), p.4, available

$a t$ :http://books.google.co.in/books/about/Gandhian_Strain_In_The_Indian_English_No.html?id=hqTqptHw2lAC (last visited on March $\left.24^{\text {th }} 2013\right)$.

${ }^{57}$ Emilsen, supra n. 6 at p.83.

${ }^{58}$ Love expressing itself is self-sacrifice, available at:http://www.mkgandhi.org/my_religion/24self_sacrificing_service.htm (last visited on March $\left.24^{\text {th }} 2013\right)$.

${ }^{59} 1$ Corinthians 13:4-8 (NIV).

${ }^{60}$ Emilsen, supra n.6 at p.85.

${ }^{61}$ VinayLal,Nakedness, Nonviolence, and Brahmacharya: Gandhi's Experiments in Celibate Sexuality, Journal of History of SexualityVol.9, p.105, available at: http://www.jstor.org/stable/3704634?seq=2(last visited on March $24^{\text {th }} 2013$ ).

${ }^{62}$ John 2:15-17 (KJV).

${ }^{63} 2$ Timothy 2:22 (KJV).

${ }_{65}^{64}$ Emilsen, supra n.6 at p.85.

${ }^{65}$ Ibid.
} 
What has not been sufficiently brought to public notice is the fact that these principles adopted and implemented by the Mahatma were inspired from the Holy Bible. However Gandhi read the Bible critically and interpreted the words in the Hindu context and never did he want to convert to Christianity as he claimed that after reading the Bible, the Bhagvat Gita was clearer to him. The Bible according to Gandhi not only broadened his view of life and perspectives but also, helped him attain peace and contentment.

Most of the Gandhian Principles, which is now collectively known as Gandhigiri, ${ }^{66}$ is inspired from the teachings of the Bible and Jesus Christ in particular. Principles including non- violence, fast unto death, holding onto truth, non-cooperation movement and the famous 'turn the other cheek', have been adopted from the Bible.

Since it was with the help of these principles that Gandhi ushered the progress of our countryand brought it independence, the researcher feels the fact that the Holy Bible and Jesus Christ had such a huge impact on Gandhi, should be acknowledged and given due credit.

\section{References}

[1]. Uma Majmudar,Gandhi's Pilgrimage of Faith: From Darkness to Light (New York: State University of New York Press, 2005 ),p.27.

[2]. Mahatma Gandhi, ch-Preparation for Englandin The Story of My Experiment with Truth (The Floating Press, 2009), pp.18-20.

[3]. William W. Emilsen, Gandhi, scripture and Bible, Pacifica Australasian Theological Studies, vol. 14, no.1, (2001), p.73.

[4]. Kathryn Tidrick, Gandhi: A Political and Spiritual Life (I. B. Tauris, 2006), p.42.

[5]. Mohandas Gandhi, Soul Force: Gandhi's Writings on Peace (Tara Publishing Ltd. 2004), p.67.

[6]. The Holy Bible, Good News Ed., Old Testament.

[7]. Dr. SarvepalliRadhakrishnan, Mahatma Gandhi (Mumbai: Jaico Publishing House, 2007), p.480.

[8]. Mahatma Gandhi, Robert Ellsberg (Ed.), Gandhi on Christianity (New York: Orbis Books, 1991), p.94.

[9]. Terrence J. Rynne, Gandhi and Jesus- The Saving Power of Non-violence (New York: Orbis Books, 2008), p.27.

[10]. Karen L. Oberst, But I Tell You (Barclay Press, 2007), P.87.

[11]. Bernard Imhasly, Goodbye to Gandhi? (New Delhi: Penguin group, 2007).

[12]. Mahatma Gandhi, William W. Emilsen, Gandhi's Bible (New Delhi: The Rev. Dr. Ashish Amos of Indian Society for Promoting Christian Knowledge, 2009), p.2.

[13]. Michael J. Nojeim, Gandhi and King: The Power of Non-Violent Resistance (Greenwood Publishing Group, 2004)

[14]. M.K. Gandhi, My Dear Child: Letters from M.K.Gandhi to Esther Faering (Navajivan, 1959).

[15]. SankarGhosh, Mahatma Gandhi (New Delhi: Allied Publishers Limited, 1991), p.229.

[16]. Ambuj Kumar Sharma, Gandhian Strain in the Indian English Novel (New Delhi: Sarup\& Sons, 2004$)$,p.4.

[17]. VinayLal, Nakedness, Nonviolence, and Brahmacharya: Gandhi's Experiments in Celibate Sexuality, Vol.9 Journal of History of Sexuality, p.10.

${ }^{66}$ Gandhigiri, available at: http://articles.timesofindia.indiatimes.com/keyword/gandhigiri (last visited on March 24 ${ }^{\text {th }} 2013$ ). The term, Gandhigiri, was brought into light after the movie 'LageRahoMunnabhai' was released in 2006. Now it's a widely used term signifying Gandhian principles. 